\title{
Nitrification mainly driven by ammonia- oxidizing bacteria and nitrite-oxidizing bacteria in an anammox-inoculated wastewater treatment system
}

\author{
Jing Lu ${ }^{1,2}$, Yiguo Hong ${ }^{1 *} \mathbb{0}$, Ying Wei ${ }^{2}$, Ji-Dong $\mathrm{Gu}^{3}$, Jiapeng Wu ${ }^{1}$, Yu Wang ${ }^{1}$, Fei Ye ${ }^{1}$ and Jih-Gaw Lin ${ }^{4}$
}

\begin{abstract}
Anaerobic ammonium oxidation (anammox) process has been acknowledged as an environmentally friendly and time-saving technique capable of achieving efficient nitrogen removal. However, the community of nitrification process in anammox-inoculated wastewater treatment plants (WWTPs) has not been elucidated. In this study, ammonia oxidation $(\mathrm{AO})$ and nitrite oxidation $(\mathrm{NO})$ rates were analyzed with the incubation of activated sludge from Xinfeng WWTPs (Taiwan, China), and the community composition of nitrification communities were investigated by high-throughput sequencing. Results showed that both $\mathrm{AO}$ and $\mathrm{NO}$ had strong activity in the activated sludge. The average rates of $A O$ and $N O$ in sample $A$ were $6.51 \mu \mathrm{mol} \mathrm{L}^{-1} \mathrm{~h}^{-1}$ and $6.52 \mu \mathrm{mol} \mathrm{L} \mathrm{L}^{-1} \mathrm{~h}^{-1}$, respectively, while the rates

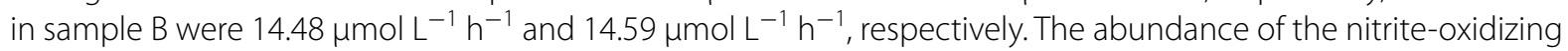
bacteria (NOB) Nitrospira was $0.89-4.95 \times 10^{11}$ copies/g in both samples A and B, the abundance of ammonia-oxidizing bacteria (AOB) was 1.01-9.74 $\times 10^{9} \mathrm{copies} / \mathrm{g}$. In contrast, the abundance of ammonia-oxidizing archaea (AOA) was much lower than AOB, only with $1.28-1.53 \times 10^{5}$ copies/g in samples $A$ and $B$. The AOA community was dominated by Nitrosotenuis, Nitrosocosmicus, and Nitrososphaera, while the AOB community mainly consisted of Nitrosomonas and Nitrosococcus. The dominant species of Nitrospira were Candidatus Nitrospira defluvii, Candidatus Nitrospira Ecomare 2 and Nitrospira inopinata. In summary, the strong nitrification activity was mainly catalyzed by AOB and Nitrospira, maintaining high efficiency in nitrogen removal in the anammox-inoculated WWTPs by providing the substrates required for denitrification and anammox processes.
\end{abstract}

Keywords: Nitrification, Anammox-inoculated WWTPs, Ammonia-oxidizing bacteria (AOB), Ammonia-oxidizing archaea (AOA), Nitrospira

\footnotetext{
${ }^{*}$ Correspondence: yghong@gzhu.edu.cn

${ }^{1}$ Key Laboratory for Water Quality and Conservation of the Pearl River Delta, Ministry of Education, Institute of Environmental Research at Greater Bay, Guangzhou University, Guangzhou 510006, People's Republic of China

Full list of author information is available at the end of the article
}

\begin{abstract}
Introduction
The discharge of nitrogen containing wastewater into natural waters has become a global concern, resulting in problems such as acidification and eutrophication (Canfield et al. 2010; Kuypers et al. 2018; Bailes et al. 2020; Lan et al. 2011). Thus, optimizing the performance of nitrogen removal in WWTPs is essential in order to control water pollution caused by the release of anthropogenic waste. Biological nitrification and denitrification
\end{abstract}


procedures have been widely applied to ammoniumrich WWTPs (Lan et al. 2011; Ali and Okabe 2015) in which ammonia is firstly transformed to nitrate via nitrification, with nitrate then converted to nitrogen gas by anoxic biotransformation using organic carbon as an electron source (Yang et al. 2020a, b). However, biological nitrification and denitrification is not the most effective process in nitrogen removal owing to the high oxygen demand of complete nitrification, the heterotrophic denitrification requires an external carbon source, accompanied by the production of sludge and nitrous oxide $\left(\mathrm{N}_{2} \mathrm{O}\right)$ (Shalini et al. 2012; Wang et al. 2018; Xin et al. 2020).

The increasing need to reduce the consumption of energy and resources by treatment systems has contributed to the development of several novel nitrogen removal techniques, such as a single reactor system for high ammonium removal over nitrite (SHARON) (Hellinga et al. 1998; Dongen et al. 2001), completely autotrophic nitrogen removal over nitrite (CANON) (Sliekers et al. 2002), oxygen-limited autotrophic nitrification-denitrification (OLAND) (Kuai et al. 1998), and anaerobic ammonium oxidation (anammox) (Jetten et al. 1998). In particular, the anammox procedure has been proven to be more efficient than conventional nitrification-denitrification process (Yang et al. 2020a, b; Ma et al. 2016; Wu et al. 2019; Bucci et al. 2020), achieving $60 \%$ reduction in oxygen demand (e.g., aeration), $90 \%$ reduction in sludge, $100 \%$ reduction in the demand for organic carbon sources and less or no $\mathrm{N}_{2} \mathrm{O}$ emission (Kartal et al. 2008; Kuenen 2008; Okabe et al. 2011; Van et al. 1995; Strous et al. 1999). The anammox reaction directly transforms ammonium and nitrite into nitrogen gas. The nitrite acts as an electron accepter in this process. (Kartal et al. 2013). However, due to the long doubling time and low typically biological yield of anammox bacteria in bioreactor systems, establishing anammoxinoculated WWTPs capable of effective inorganic nitrogen removal is time-consuming compared to conventional WWTP processes (Ali et al. 2015; Awata et al. 2013; Cho et al. 2011; Strous et al. 1998; van et al. 2007). In general, visible anammox bacterial granules are not observed until 6-9 months after the initial inoculation of WWTPs (Meng et al. 2017; Yang et al. 2018; Azari et al. 2017). The highthroughput sequencing technique was used to further revealing the composition of the main microorganism community in WWTPs (Yang et al. 2020a, b).

Previous researches on nitrogen removal in WWTPs focused on the denitrification and anammox processes, which transformed nitrate and nitrite to nitrogen gas (Ali and Okabe 2015; Yang et al. 2020a, b; Ali et al. 2015). In anammox-inoculated WWTPs, various types of microbial pathways play significant roles in the procedure of nitrogen transformation especially the anammox process occupy the main position. Denitrification is an important process for nitrogen removal while nitrification is an essential intermediate process transforming ammonia to nitrite or nitrate. However, despite nitrification being an essential and rate-limiting step in microbial nitrogen-cycling networks, the role of nitrification in anammox-inoculated WWTPs has not been comprehensively understood in current available researches (Cortés-Lorenzo et al. 2015; Wang et al. 2018; Xin et al. 2020; Egli et al. 2003; Zheng et al. 2017) and the community microbial activity of the major nitrifiers in anammox-driven WWTPs remain unknown. A more complete understanding of nitrification can increase the efficiency of nitrogen removal in anammox-inoculated WWTPs.

In this research, the microbial communities related to nitrification were studied in an anammox-inoculated WWTPs, including ammonia-oxidizing bacteria (AOB), ammonia-oxidizing archaea (AOA), and nitrite-oxidizing bacteria (NOB). The aims of this project were to (i) determine the potential nitrification rates (including rates of $\mathrm{AO}$ and NO); (ii) analyse the community composition of the key functional microbes contributing to nitrification in the wastewater treatment ecosystem; and (iii) understand the role of nitrification in the anammox-inoculated WWTPs.

\section{Materials and methods \\ Description of the anammox-inoculated WWTPs and sample collection}

The activated sludge samples used in this study were obtained from an anammox bacteria inoculated aeration tank in Xinfeng WWTPs in Taiwan, the northeast of China. The WWTPs were used for treating mixed wastewater including landfill leachate wastewater, car washing wastewater, and fertilizer wastewater (Yang et al. 2020a, b). Fresh activated sludge samples were collected from the aeration tank (sample A and sample B were collected on May 13th 2019 and October 12th 2019, respectively) using $500 \mathrm{~mL}$ polypropylene bottles, then stored with ice packs during the transportion to the laboratory. The collected samples were firstly divided into two parts. Then, one part of samples were stored in the refrigerator at $4{ }^{\circ} \mathrm{C}$ for rates analysis, the other part were stored in the refrigerator at $-20{ }^{\circ} \mathrm{C}$ for the analysis of community composition and abundance.

\section{Nitrification rate measurements}

The AO and NO rates were calculated using methods previously described by Hong (Hong et al. 2018). Briefly, the $250 \mathrm{~mL}$ sterile wide-mouth bottles were used to incubate samples (HDPE, Thermo Fisher Scientific, US) containing $1 \mathrm{~g}$ activated sludge slurry, which were then incubated at $28{ }^{\circ} \mathrm{C}$ with continual agitation at $75 \mathrm{rpm}$ to maintain aerated conditions. To decrease dissolved inorganic nitrogen (DIN) assimilation by phytoplankton, samples were cultured in the dark. The incubation supernatant was sampled every $6 \mathrm{~h}$ for 
measurement of ammonia, nitrite, and nitrate concentrations. The previous research has suggested that mathematical modeling methods are more suitable for the analysis of nitrification rates because nitrification was a non-linear dynamic process (Hong et al. 2018). Large errors will introduce if nitrification rates are calculated via using only two or three data points to establish linear regression. Therefore, a mathematical modeling method was adopted in the present study (Fig. 1). Firstly, the corresponding mathematical equation was obtained by fitting a smoothed time series of DIN concentration using the Boltzmann distribution pattern. The fitted $\mathrm{NO}_{\mathrm{x}}{ }^{-}$curves were used to calculate the average rates of $\mathrm{AO}\left(\mathrm{V}_{\mathrm{a}}\right.$, Eq. (1)) and $\mathrm{NO}\left(\mathrm{V}_{\mathrm{n}}\right.$, Eq. (2)). Then, instantaneous $\mathrm{V}_{\mathrm{a}}$ and $\mathrm{V}_{\mathrm{n}}$ equations and curves were calculated according to the first derivative of the fitting curves (Fig. 1).
The average and instantaneous data parameters (including maximum instantaneous data points) were suggested in Fig. 2. The three indices $\left(\mathrm{V}_{\mathrm{a}}, \mathrm{V}_{\mathrm{n}}\right.$ and their maximum value) described the average nitrification potential and maximum nitrification potential of a sample. The dynamic process of nitrification in samples was depicted in Fig. 1. The index of nitrogen balance (INB) was used to make an estimation with the total amount of variability of DIN in the incubation system (Eq. (3)).

$$
\begin{aligned}
& \overline{V_{a}}=\frac{\left[\mathrm{NO}_{3}^{-}+N \mathrm{NO}_{2}^{-}\right]_{\text {final }}\left[\mathrm{NO}_{3}^{-}+\mathrm{NO}_{2}^{-}\right]_{\text {initial }}}{\Delta T} \\
& \overline{V_{n}}=\frac{\left[\mathrm{NO}_{3}^{-}\right]_{\text {final }}-\left[\mathrm{NO}_{3}^{-}\right]_{\text {initial }}}{\Delta T}
\end{aligned}
$$
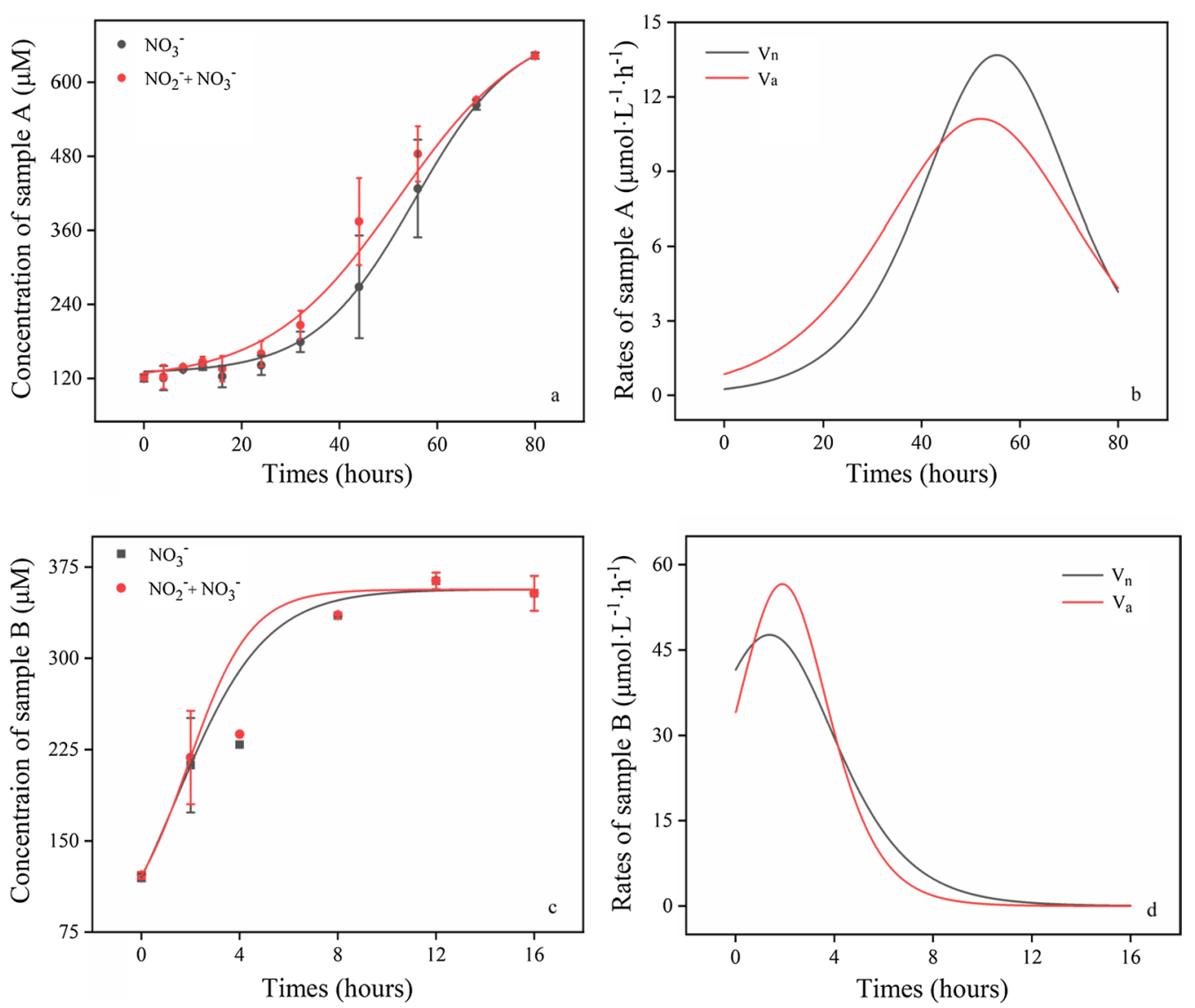

Fig. 1 Boltzmann fitted curves $(\mathbf{a}, \mathbf{c})$ and differential curves $(\mathbf{b}, \mathbf{d})$ from Boltzmann fitting equations of the DIN time series for instantaneous rates of ammonia oxidation $(\mathrm{Va})$ and nitrite oxidation $(\mathrm{Vn})$ of the water samples 


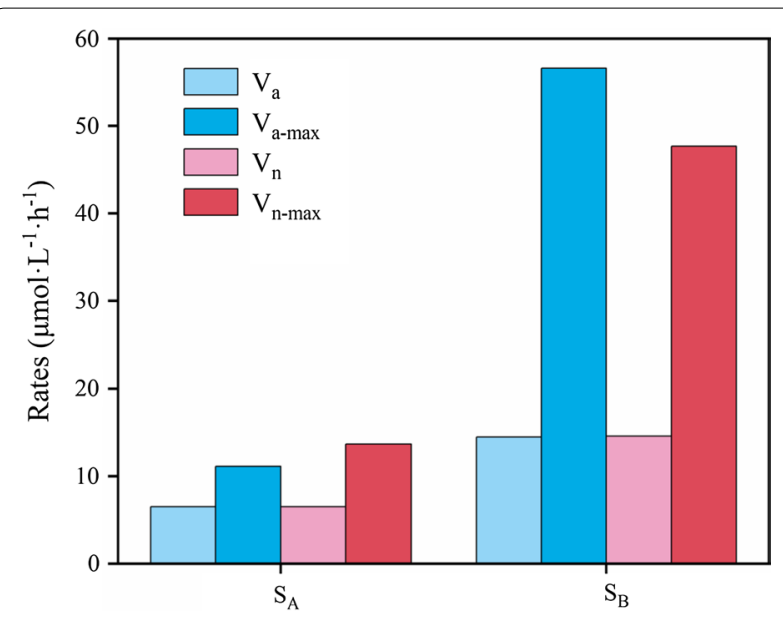

Fig. 2 Average and maximum rates of ammonia oxidation and nitrite oxidation

\section{DNA extraction and PCR amplification}

Total DNA was extracted $0.3 \mathrm{~g}$ from each sample using a PowerSoil DNA isolation kit (Mo Bio, CA, US), then stored it in the refrigerator with temperature of $-80{ }^{\circ} \mathrm{C}$ for further analysis. The NanoDrop Lite spectrophotometer (Thermo Fisher Scientific, DE, US) was used to determine the concentration of extracted DNA. Using extracted DNA as a template, the respective primer pairs (Arch-amoAF/ArchamoAR, amoA-1F/amoA-2R, Nxr-f27/Nxr-r617) were used to participate in the PCR amplification targeting archaeal amoA, bacterial amoA, and $n x r B$ genes separately (Reddy et al. 2014; Rotthauwe et al. 1997; Hong et al. 2020). Optimized PCR was run using mixtures with a total amount of $25 \mu \mathrm{L}$, composed of 12.5 $\mu \mathrm{L}$ of GoTaq Green Master Mix (Promega, US), $1 \mu \mathrm{L}$ of forward and reverse primers $(15 \mu \mathrm{M}), 1 \mu \mathrm{L}$ of template DNA, and $9.5 \mu \mathrm{L}$ of $\mathrm{ddH}_{2} \mathrm{O}$. The thermocycler program for archaeal $a m o A$ and bacterial $a m o A$ was shown below: $95{ }^{\circ} \mathrm{C}$ for $3 \mathrm{~min}$, followed by 35 cycles of $95{ }^{\circ} \mathrm{C}$ for $45 \mathrm{~s}, 53{ }^{\circ} \mathrm{C}$ for $45 \mathrm{~s}$, and $72{ }^{\circ} \mathrm{C}$ for $45 \mathrm{~s}$, finally followed by elongation at $72{ }^{\circ} \mathrm{C}$ for $10 \mathrm{~min}$. The thermocycler program for $n \times r B$ was shown below: $95{ }^{\circ} \mathrm{C}$ for $2 \mathrm{~min}$, followed by 32 cycles of $95^{\circ} \mathrm{C}$ for $45 \mathrm{~s}$, $62{ }^{\circ} \mathrm{C}$ for $45 \mathrm{~s}$, and $72{ }^{\circ} \mathrm{C}$ for $45 \mathrm{~s}$, finally followed by elongation at $72{ }^{\circ} \mathrm{C}$ for $5 \mathrm{~min}$. The NanoDrop spectrophotometer (NanoDrop Technologies, DE, US) and MiniBEST agarose gel DNA extraction kit (TaKaRa, Beijing, China) were used to check the concentration of PCR products and purify the products respectively. Then, stored it in a single tube for high-throughput sequencing. Finally, the PCR products through purification were sequenced on the Illumina MiSeq platform.

\section{High-throughput sequencing analysis}

High-throughput sequencing was performed according to the standard protocol described in previously studies using Mothur software v.1.40.5 (Schloss et al. 2009; Wu et al. 2018; He et al. 2016). Tags and primers were firstly removed from the obtained sequences. Then, the qualitytrimmed sequences were aligned to the gene database including sequences for amoA-AOA (He 2018), amoAAOB (The 16S rRNA gene sequences of the identified strains and uncultured sequences from environmental samples as seed sequences in database were obtained from NCBI and Fungene), and $n x r B$ (Jiao et al. 2018). The seqs. command was applied to filter and remove badly aligned sequences, while the commands pre.cluster, chimera.uchime and remove.seqs were used to reduce errors and remove chimeric sequences. Operational taxonomic units (OTUs) were identified using 0.06, 0.13, and 0.06 cut off values for OTU clustering of $\mathrm{AOA}, \mathrm{AOB}$, and Nitrospira, respectively.

\section{Real-time quantitative PCR}

The abundance of nitrifier prokaryotes was determined by real-time PCR (Q-PCR) using an Eco Real-Time PCR System (Ilumia, CA, US) with SYBR Green PCR Master Mix (Promega, US). Q-PCR was run with a $15 \mu \mathrm{L}$ reaction mixture containing $1.0 \mu \mathrm{L}$ template DNA, $0.1 \mu \mathrm{L}$ of forward and reverse primers respectively, $6.3 \mu \mathrm{L} \mathrm{ddH}_{2} \mathrm{O}$ and $7.5 \mu \mathrm{L}$ SYBR Green PCR Master Mix. The primers Arch-amoAF/Arch-amoAR were used for the quantification of archaeal $a m o A$ gene, with a PCR condition starting at $95{ }^{\circ} \mathrm{C}$ for $3 \mathrm{~min}$, followed by 45 cycles of $30 \mathrm{~s}$ at $95{ }^{\circ} \mathrm{C}, 45 \mathrm{~s}$ at $53{ }^{\circ} \mathrm{C}$ and $1 \mathrm{~min}$ at $72{ }^{\circ} \mathrm{C}$. The primers Nxrf27/Nxr-r617 were used for Nitrospira $n x r B$ gene quantification, with a PCR condition starting at $95^{\circ} \mathrm{C}$ for $2 \mathrm{~min}$, followed by 40 cycles of $45 \mathrm{~s}$ at $95{ }^{\circ} \mathrm{C}, 45 \mathrm{~s}$ at $62{ }^{\circ} \mathrm{C}$ and $45 \mathrm{~s}$ at $72{ }^{\circ} \mathrm{C}$. The primers amoA-1F/amoA-2R were used for bacterial $a m o A$ gene quantification, with a PCR condition starting at $95{ }^{\circ} \mathrm{C}$ for $3 \mathrm{~min}$, followed by 40 cycles of $15 \mathrm{~s}$ at $95{ }^{\circ} \mathrm{C}, 1 \mathrm{~min}$ at $55^{\circ} \mathrm{C}$, and $1 \mathrm{~min}$ at $72{ }^{\circ} \mathrm{C}$. The Plasmid Mini Preparation Kit (Tiagen, China) was used to extract plasmids containing the targeted gene fragments from E.coli hosts. The extracted plasmid DNA with tenfold serial dilutions was used to obtain the standard curves. Samples and standards were determined in triplicate and average values were calculated. Melt curves generating in each assay were applied to check the specificity of the amplified products.

\section{Nucleotide data of high throughput deposition}

The nucleic acid sequences of high throughput used in this study was deposited in the National Omics Data Encyclopedia (NODE). The accession number of archaeal 
amo $A$ gene, bacterial $a m o A$ gene and $n x r B$ gene were OEP002783, OEP002784, OEP002785, respectively.

\section{Results}

\section{Time series of DIN during incubations}

Time series of ammonia, nitrite, and nitrate concentrations during the incubations of sample $\mathrm{A}\left(\mathrm{S}_{\mathrm{A}}\right)$ and sample B $\left(\mathrm{S}_{\mathrm{B}}\right)$ were displayed in Fig. 3.

In the incubation of sample $A$, nitrate began to increase in accordance with a reduction in ammonia. Nitrate of sample A did not reach its maximum concentration until the nitrite was below the detection limit. Correspondingly, the variation in $\mathrm{NO}_{\mathrm{x}}{ }^{-}$concentrations (nitrite and nitrate) presented the same trend to that of $\mathrm{NO}_{3}{ }^{-}$. The concentration of nitrite increased slowly, reaching a maximum level $\left(105.88 \mu \mathrm{mol} \mathrm{L}^{-1}\right)$ at $44 \mathrm{~h}$, then it began to decrease. As $\mathrm{INB}<1.0$, it was indicated that the nitrogen was lost owing to diffenent possible ways such as denitrification, anammox and assimilation by phytoplankton.
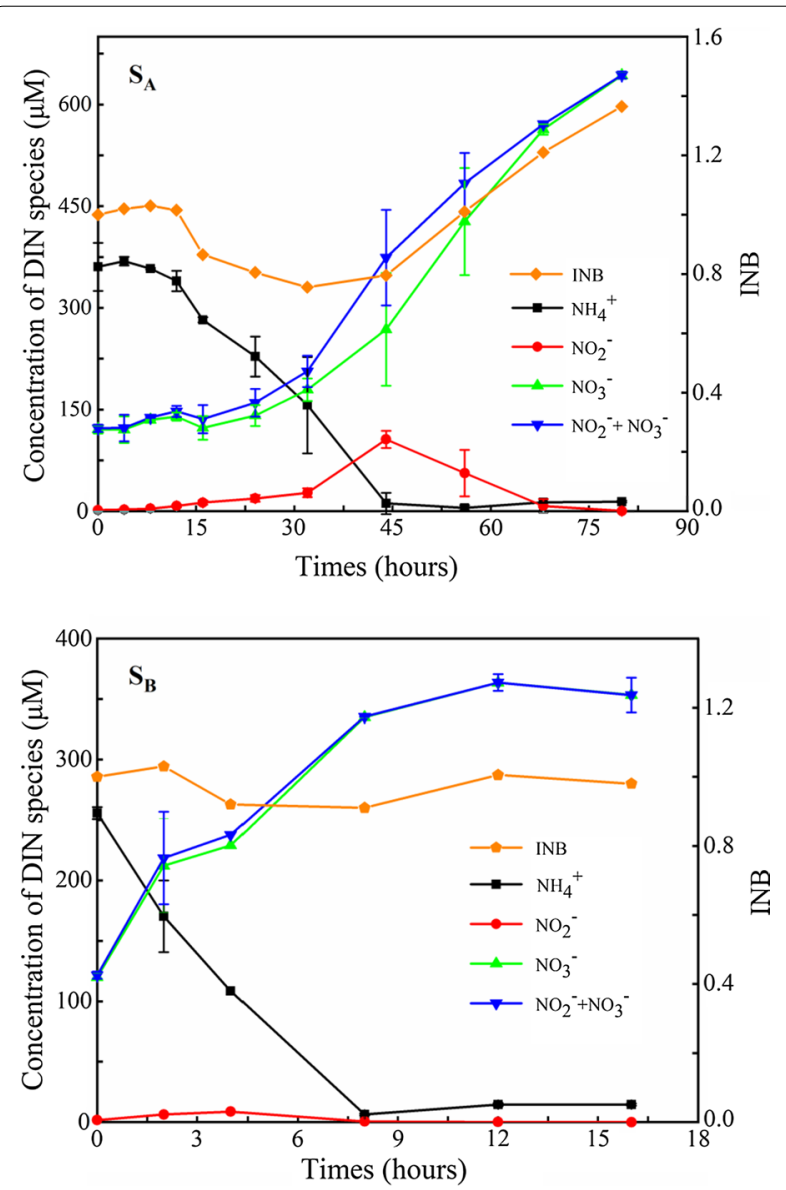

Fig. 3 Time series for the concentrations of ammonium, nitrite and nitrate in the activated sludge of the aeration tank in Xinfeng WWTPS. Error bars represent standard variation $(S D, n=3)$
When INB $>1.0$, it was resulted form the organic mineralization in the incubation (Hong et al. 2018). The INB value of sample A firstly decreased from 1.0 to 0.8 at the initial stage of incubation and then began to increase from 0.8 to 1.37, suggesting that assimilation and mineralization co-occurred in the period. Also, the change was closely related to the accumulation of nitrite.

The trend of DIN variation in sample B was inclined to be different from that of sample A. The ammonia concentration gradually decreased at a relatively stable rate, reaching a minimum concentration $\left(6.34 \mu \mathrm{mol} \mathrm{L}^{-1}\right)$ at $8 \mathrm{~h}$. No remarkable nitrite accumulation was observed in the incubation period, suggesting that the rate of $\mathrm{NO}$ was equal to or stronger than the rate of AO. The nitrite concentration increased slowly, reaching a maximum level $\left(8.66 \mu \mathrm{mol} \mathrm{L}^{-1}\right)$ at $4 \mathrm{~h}$ and then reducing to very low level at $8 \mathrm{~h}$. Due to the absence of nitrite accumulation, the time series of nitrate variation followed a similar trend to that of the sum of nitrate and nitrite. In the incubation of sample B, the INB value remained stable at about 1.0.

\section{Ammonia oxidation and nitrite oxidation rates}

For samples A and B, the Boltzmann fitted curves for both $\mathrm{V}_{\mathrm{a}}$ and $\mathrm{V}_{\mathrm{n}}$ exhibited similar patterns with an initial lag phase, an exponential growth phase, and a plateau phase. Based on the fitted curve data, the average $V_{a}$ and $\mathrm{V}_{\mathrm{n}}$ values in sample A were calculated as $6.51 \mu \mathrm{mol} \mathrm{L} \mathrm{L}^{-1}$ $\mathrm{h}^{-1}$ and $6.52 \mu \mathrm{mol} \mathrm{L}^{-1} \mathrm{~h}^{-1}$ respectively, while the average $\mathrm{V}_{\mathrm{a}}$ and $\mathrm{V}_{\mathrm{n}}$ values in sample $\mathrm{B}$ were $14.48 \mu \mathrm{mol} \mathrm{L}^{-1} \mathrm{~h}^{-1}$ and $14.59 \mu \mathrm{mol} \mathrm{L}^{-1} \mathrm{~h}^{-1}$, respectively (Fig. 2).

The equations and curves of instantaneous $V_{a}$ and $V_{n}$ values (Fig. $1 \mathrm{~b}$ and $\mathrm{d}$ ) were established based on the first derivative of the fitted curves (Fig. 1a and c). The dynamic characteristics of $\mathrm{V}_{\mathrm{a}}$ and $\mathrm{V}_{\mathrm{n}}$ was clearly exhibited in the instantaneous rate curves in the incubations of sludge samples. In the incubation of sample A, both instantaneous $\mathrm{V}_{\mathrm{a}}$ and $\mathrm{V}_{\mathrm{n}}$ were inclined to present the characteristics of first increasing and then decreasing. After a slow period of growth lasting for about $20 \mathrm{~h}, \mathrm{~V}_{\mathrm{a}}$ and $\mathrm{V}_{\mathrm{n}}$ began to increase at a faster rate and reached their maximum levels of $11.11 \mu \mathrm{mol} \mathrm{L} \mathrm{L}^{-1} \mathrm{~h}^{-1}$ and $13.68 \mu \mathrm{mol} \mathrm{L}^{-1} \mathrm{~h}^{-1}$ by $50 \mathrm{~h}$, then gradually declined until the end of the incubation period (Fig. 1). However, the instantaneous $V_{a}$ and $V_{n}$ curves of sample $B$ were significantly different from those in sample A. Both instantaneous $V_{a}$ and $V_{n}$ maintained a declining trend in the incubation period, resulting in the initial $V_{a}$ and $V_{n}$ values their maximum values were $7.6 \mu \mathrm{mol} \mathrm{L}^{-1} \mathrm{~h}^{-1}$ and $11.11 \mu \mathrm{mol} \mathrm{L}^{-1} \mathrm{~h}^{-1}$, respectively.

\section{The abundance of microbial communities in nitrification}

The abundances of AOA, AOB and NOB communities were estimated via the genes $a m o A$ and $n x r B$ using the 

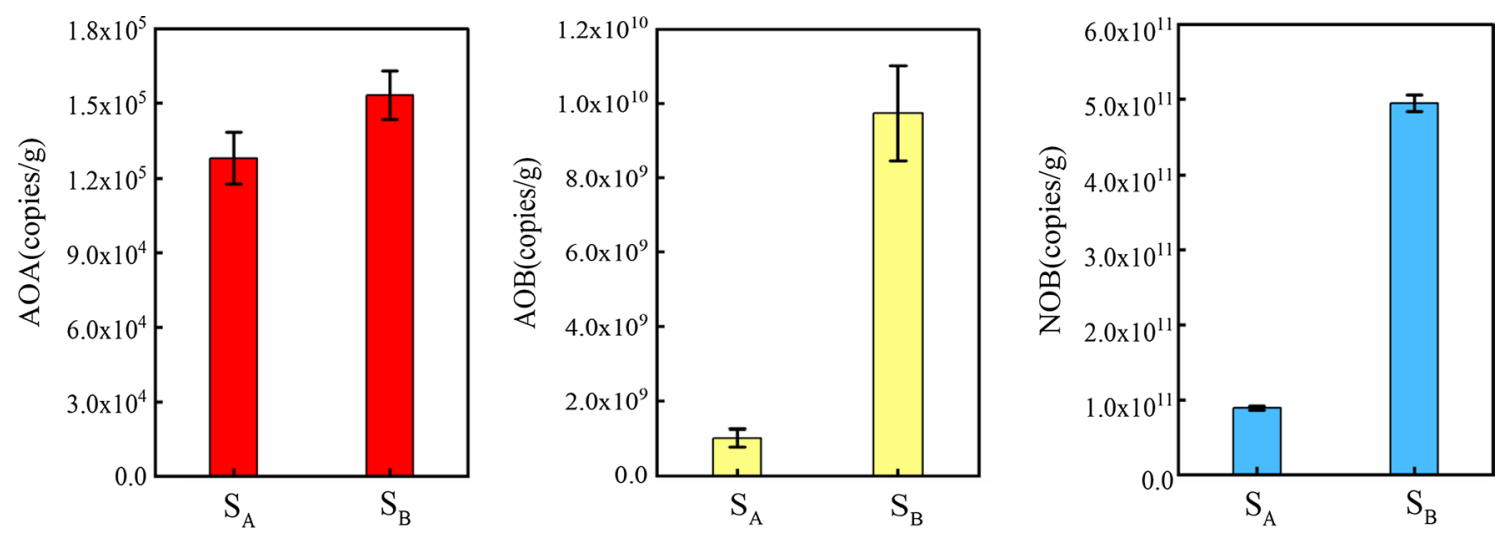

Fig. 4 Abundances of $A O A, A O B$ and $N O B$ in the aeration tank of Xinfeng WWTPs

qPCR method. The abundance of AOA was the lowest in the microbial communities, ranging from $1.2 \times 10^{5}$ to $1.5 \times 10^{5}$ copies/g sludge (Fig. 4). In comparison, the abundance of $\mathrm{AOB}$ was 4 orders of magnitude higher than AOA, ranging from $1.0 \times 10^{9}-9.7 \times 10^{9}$ copies $/ g$ sludge. However, the abundance of NOB Nitrospira was found to be 1-2 orders of magnitude higher than that of AOB.

\section{OTU-level composition of nitrification microbial communities}

All the raw sequences obtained via high-throughput sequencing were subjected to quality control processing, trimming, filtering, and removing low-quality sequences to obtain a total of 489, 24,524, and 14,283 high-quality AOA, $\mathrm{AOB}$ and $\mathrm{NOB}$ functional gene sequences, respectively.

The AOA, AOB and NOB community composition was shown in Fig. 5. Based on the 0.06 distance level, a total of 12 dominant OTUs were obtained for the AOA amoA gene. About half of these sequences were attributed to three known genera, including Nitrosotenuis (33.33\%), Nitrososphaera (8.33\%), and Nitrosocosmicus (8.33\%) (Fig. 5a). Similarly, 154 dominant OTUs were obtained for the AOB amoA gene at the 0.13 distance level, which were assigned to four species. Nitrosomonas $s p$. was the most dominant (79.75\%), followed by Nitrosococcus $s p$. $(0.91 \%)$, with only a small portion classified as specific species, including Nitrosomonas europaea (0.61\%) and Nitrosomonas oligotropha (1.96\%) (Fig. 5b). Among the NOB community, 1556 dominant OTUs were obtained at the 0.06 distance level, the majority of which were not affiliated with any known genera (74.29\%), while the remaining sequences were classified as Candidatus Nitrospira defluvii (17.74\%), Nitrospira inopinata (5.01\%), Candidatus Nitrospira Ecomare2 (2.63\%), and others (0.32\%) including Nitrospira japonica and Nitrospira marina (Fig. 5c).

\section{Discussion}

Despite sample A and B were collected at different times from the anammox-inoculated wastewater treatment tank, the variation of time series of DIN in two samples exhibited similar trends. Sample A and sample B were collected in different seasons with similar temperature. Therefore, sampling times may be a major element affecting the nitrification activity of activated sludge in this study. The nitrification activity of sample A was weaker than that of sample B, which may be related to the

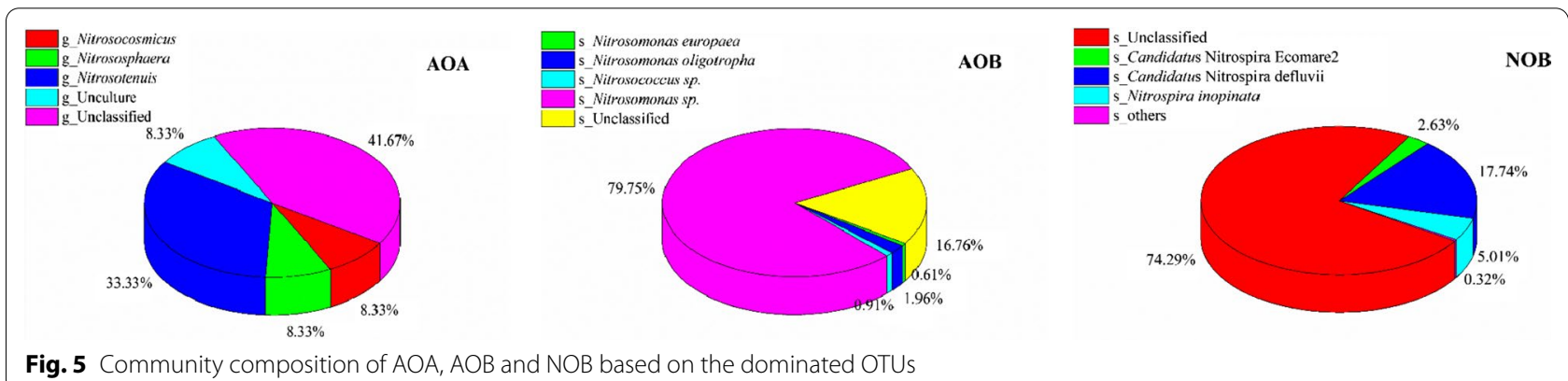

Fig. 5 Community composition of $A O A, A O B$ and $N O B$ based on the dominated OTUs 
various sampling times of activated sludge. In the incubation period of sample A, nitrite was accumulated that associated with substrates provided by the $\mathrm{AO}$ process. However, NOB had the highest abundance among the nitrification community which represented that the oxidation of nitrite may be delayed while NO activity may need induction with sufficient nitrite concentrations. In the incubation of sample B, almost no nitrite accumulation was observed, indicating a high NO capability and highlighting the different active function states in sample B compared to sample A.

Results showed that the instantaneous rates of $\mathrm{V}_{\mathrm{a}}$ were initially higher than $V_{n}$ for both sample $A$ and $B$, then the instantaneous rates of $V_{n}$ gradually exceeded that of $V_{a}$ in the incubation (Fig. 1). The instantaneous rates of both $V_{a}$ and $V_{n}$ were higher in sample $B$ than sample $A$, with the maximum rate of $V_{a}$ in sample $B$ being fivefold higher than sample $A$, while the maximum rate of $V_{n}$ in sample $B$ was more than threefold higher than that of sample A. Furthermore, after the maximum rates were achieved, the reduction in rates observed in sample $B$ were faster than that of sample A, which were consistent with the observed rates of $\mathrm{NO}$, which tended to be higher than that of AO in sample B (Fig. 3).

The abundance of $\mathrm{AOB}$ performed higher than that of AOA in sludge, indicating that $\mathrm{AOB}$ played a dominant role in AO (Fig. 4). This result was similar to the majority of consequences in former researches that suggested the AOB amoA gene abundance was typically 2-4 orders of magnitude higher than that of AOA (Jin et al. 2010; Limpiyakorn et al. 2011; Wells et al. 2009; Yapsakli 2010). The abundance of AOB has been reported to be higher than AOA in $\mathrm{NH}_{3}{ }^{+}$rich environments (Yang et al. 2016), with Nitrosomonas AOB usually detected in this circumstance (Ke et al. 2012; Wang et al. 2013). However, some previous studies have suggested that the dominance of AOMs may not directly be related to their contribution to ammonia oxidation, they showed the process was mediated mainly by AOA though AOB was more abundant (Pan et al. 2018a, b; Niu et al. 2013). In the current study, the copy numbers of NOB in this study have exceeded many previous studies from various environmental habitats such as Chinese WWTPs (Pan et al. 2018a, b), Drinking Water Treatment Plants sludge (DWTPs) (Flower et al. 2018), freshwater recirculating aquaculture systems (Bartelme et al. 2017), and soils (Hu et al. 2017).

The abundances of all three nitrification microbial communities in sample A were lower than that of sample $B$ as well as the abundances of $A O B$ and NOB in sample $B$ were tenfold and fivefold higher than sample A, respectively (Fig. 4). The most previous studies focused on ammonia-oxidizing microbes, neglecting the important role of nitrite-oxidizing microbes (Gao et al. 2018; Zhang et al. 2018; Meng et al. 2017; Ali et al. 2015). The results of the present study show that the activated sludge had strong nitrite oxidation activity besides ammonia oxidation activity.

Except the cultured three known genera of AOA, the rest of its community were composed of uncultured or unclassified genera because of the limited size of $16 \mathrm{~S}$ reads and various databases via ambiguous classification. Some new AOA species existing in the system was possible which was similar to the study of nitrifying archaeal in the north Pacific (Semedo et al. 2021). As we known, the Nitrosomonas was dominant species in AOB. Among the Nitrosomonas bacterial community, all species were unclassified species except for Nitrosomonas europaea and Nitrosomonas oligotropha. Nitrosomonas was one of the most common genera found to be responsible for AO in WWTPs (Coskuner et al. 2002; Siripong et al. 2007; Wang et al. 2012). These findings were consistent with previous results for Xinfeng WWTPs (Yang et al. 2020a, b), suggesting that Nitrosomonas was the only $\mathrm{AOB}$ genus exhibiting significant levels of enrichment in the incubation. NOB Nitrospira was found to be the main contributor of $\mathrm{NO}$ in this study. However, there are many bacterial genera known to be capable of NO, with the known nitrite oxidizing genera including Nitrospira, Nitrobacter, Nitrotoga, Nitrococcus, Nitrospina, and Nitrolancea (STéPHANIE et al. 1994; Alawi et al. 2009; Daims et al. 2016). In particular, previous studies have suggested that Nitrobacter was a driver of NO in biological WWTPs (Gieseke et al. 2003). Then, the later researches found both Nitrobacter and Nitrospira existed in municipal WWTPs (Siripong et al. 2007). Nitrospira played a key role in the NOB community in activated sludge and nitrifying fluidized bed reactors especially in WWTPs of nitrite limitation due to the competitive advantage provided by the periplasmic nitrite oxidoreductase (NXR) (Yang et al. 2020a, b; Hovanec et al. 1996; Hovanec et al. 1998; Juretschko et al. 1998; Schramm et al. 1998; Wagner et al. 1996; Yang et al. 2021; Daims et al. 2016). But Nitrobacter sp. were found to be dominant rather than Nitrospira sp. in the nitrifying systems of coke WWTPs and in bioreactors treating high strength wastewater (Cho et al. 2014; Kim et al. 2011a, b; Figuerola et al. 2010; Kim et al. 2011a, b). It was also suggested that NOB Nitrotoga was generally detected in WWTPs at low temperatures (Alawi et al. 2009). Therefore, the actual abundance of NOB in Xinfeng WWTPs may be much higher than the level reported in the present study owing to the similar temperatures of sampling times and the same sampling location. 


\section{Implication for regulating the nitrification process}

Anammox has been identified in recent decades as an efficient and cost-effective pathway for $\mathrm{N}$ removal using $\mathrm{NH}_{4}{ }^{+}$and $\mathrm{NO}_{2}{ }^{-}$as substrates to generate $\mathrm{N}_{2}$ gas without the production of $\mathrm{N}_{2} \mathrm{O}$ in anaerobic environments ( $\mathrm{Li}$ et al. 2020; Yang et al. 2020a, b; Meng et al. 2021). Although anammox plays an important part in the Xinfeng anammox-inoculated WWTPs, it couldn't replace the effect of the combined network composed of nitrification, denitrification and anammox pathways in $\mathrm{N}$ removal. In ammonium-rich wastewater treatment, microbial nitrification is an indispensable process, which was a significant limiting-rate step in the nitrogen removal process, connecting mineralization and nitrogen loss processes (Kuypers et al. 2018; Zhang et al. 2018; Zhou et al. 2015; Yang et al. 2021). Through the nitrification process, microorganisms can transform ammonia into nitrite and nitrate (Yang et al. 2020a, b; Yang et al. 2018; Wang et al. 2021), providing effective substrates for both the anammox and denitrification processes, ensuring effective nitrogen removal by the whole treatment system (Additional file 1).

Notably, a certain concentration of nitrite helps to maintain efficient anammox processes in nitrification. However, high of NO was observed, with the activity exceeding that of $\mathrm{AO}$, inhibiting nitrite accumulation (Fig. 2). Subsequently, the anammox process would be weakened. Therefore, appropriate inhibition of $\mathrm{NOB}$ activity in the treatment system would be an alternative method for improving the anammox activity in anammox-inoculated WWTPs, avoiding an increase in operational costs and a reduction in nitrogen removal efficiency caused by the lack of nitrite accumulation. Overall, establishing methods to regulate the nitrification process is an important issue and the composition and activity of NOB community in anammox-inoculated WWTPs should be pay more attention in future studies.

\section{Supplementary Information}

The online version contains supplementary material available at https://doi. org/10.1186/s13568-021-01321-6.

Additional file 1. Table $\mathbf{S 1}$ The monitoring data of Xinfeng WWTPs on May 13th. Table S2 The monitoring data of Xinfeng WWTPs on October 12th. Figure S1 The sewage treatment process flow chart of Xinfeng. (Wang et al. 2021).

\section{Acknowledgements}

Authors are thankful to Dr. Qiaoyan Wei for helping sampling the actived sluge from Xinfeng WWTPs in Taiwan.

\section{Authors' contributions}

JL: Investigation, methodology, experiments, writing original draft; YGH, JPW, $J G L$ : Writing-reviewing and editing, supervision; YW: Methodology, experiments; JDG: Writing-reviewing, visualization; YW and YF: Methodology, visualization, software. All authors read and approved the final manuscript.

\section{Funding}

This work was supported by the National Natural Science Foundation of China (Grant Nos. 91851111 and 31870100), Natural Science Foundation of Guangdong Province (Grant No. 2019B1515120066).

\section{Availability of data and materials}

The data of nucleic acid sequences were deposited in the National Omics Data Encyclopedia (NODE) with accession number OEP002783, OEP002784 and OEP002785 for archaeal amoA gene, bacterial amoA gene and $n \times r B$ gene, respectively.

\section{Declarations}

Ethics approval and consent to participate Not applicable.

\section{Consent for publication}

Not applicable.

\section{Competing interests}

The authors declare that they have no conflicts of interest with respect to the work described in this manuscript.

\section{Author details}

${ }^{1}$ Key Laboratory for Water Quality and Conservation of the Pearl River Delta, Ministry of Education, Institute of Environmental Research at Greater Bay, Guangzhou University, Guangzhou 510006, People's Republic of China.

${ }^{2}$ School of Environmental Science and Engineering, Guangzhou University, Guangzhou, China. ${ }^{3}$ Environmental Engineering, Guangdong Technion Israel Institute of Technology, 241 Daxue Road, Shantou 515063, Guangdong, China. ${ }^{4}$ Institute of Environmental Engineering, National Chiao Tung University, 1001 University Road, Hsinchu City 30010, Taiwan.

Received: 15 October 2021 Accepted: 16 November 2021

Published online: 27 November 2021

\section{References}

Alawi M, Off S, Kaya M, Spieck E (2009) Temperature influences the population structure of nitrite-oxidizing bacteria in activated sludge. Environ Microbiol Rep 1(3):184-190

Ali M, Okabe S (2015) Anammox-based technologies for nitrogen removal: advances in process start-up and remaining issues. Chemosphere 141(DEC):144-153

Ali M, Oshiki M, Awata T, Isobe K, Kimura Z, Yoshikawa H, Hira D, Kindaichi T, Satoh H, Fujii T, Okabe S (2015) Physiological characterization of anaerobic ammonium oxidizing bacterium 'Candidatus Jettenia caeni'. Environ Microbiol 17(6):2172-2189

Awata T, Oshiki M, Kindaichi T, Ozaki N, Ohashi A, Okabe S (2013) Physiological characterization of an anaerobic ammonium-oxidizing bacterium belonging to the "Candidatus scalindua" group. Appl Environ Microbiol 79(13):4145-4148

Azari M, Walter U, Rekers V, Gu J-D, Denecke M (2017) More than a decade of experience of landfill leachate treatment with a full-scale anammox plant combining activated sludge and activated carbon biofilm. Chemosphere 174:117-126

Bailes IR, Gröcke DR (2020) Isotopically labelled macroalgae: A new method for determining sources of excess nitrogen pollution. Rapid Commun Mass Spectrom 34(24):e8951

Bartelme RP, McLellan SL, Newton RJ (2017) Freshwater recirculating aquaculture system operations drive biofilter bacterial community shifts around a stable nitrifying consortium of ammonia-oxidizing archaea and comammox Nitrospira. Front Microbiol 8:101

Bucci P, Coppotelli B, Morelli I, Zaritzky N, Caravelli A (2020) Simultaneous heterotrophic nitrification and aerobic denitrification of wastewater in granular reactor: microbial composition by next generation sequencing analysis. J Water Process Eng 36:101254

Canfield DE, Glazer AN, Falkowski PG (2010) The evolution and future of Earth nitrogen cycle. Science 330(6001):192-196 
Cho S, Fujii N, Lee T, Okabe S (2011) Development of a simultaneous partial nitrification and anaerobic ammonia oxidation process in a single reactor. Bioresour Technol 102(2):652-659

Cho KH, Kim J-O, Kang S, Park H, Kim S, Kim YM (2014) Achieving enhanced nitrification in communities of nitrifying bacteria in full-scale wastewater treatment plants via optimal temperature and $\mathrm{pH}$. Sep Purif Technol 132:697-703

Cortés-Lorenzo C, Rodríguez-Díaz M, Sipkema D, Juárez-Jiménez B, Rodelas B, Smidt H, González-López J (2015) Effect of salinity on nitrification efficiency and structure of ammonia-oxidizing bacterial communities in a submerged fixed bed bioreactor. Chem Eng J 266:233-240

Coskuner G, Curtis TP (2002) In situ characterization of nitrifiers in an activated sludge plant: detection of Nitrobacter Spp. J Appl Microbiol 93(3):431-437

Daims H, Lücker S, Wagner M (2016) A new perspective on microbes formerly known as nitrite-oxidizing bacteria. Trends Microbiol 24(9):699-712

Devivaraprasad Reddy A, Subrahmanyam G, Shivani Kallappa G, Karunasagar I, Karunasagar I (2014) Detection of ammonia-oxidizing archaea in fish processing effluent treatment plants. Indian J Microbiol 54(4):434-438

Egli K, Bosshard F, Werlen C, Lais P, Siegrist H, Zehnder AJB, van der Meer JR (2003) Microbial composition and structure of a rotating biological contactor biofilm treating ammonium-rich wastewater without organic carbon. Microb Ecol 45(4):419-432

Figuerola ELM, Erijman L (2010) Diversity of nitrifying bacteria in a full-scale petroleum refinery wastewater treatment plant experiencing unstable nitrification. J Hazard Mater 181(1):281-288

Fowler SJ, Palomo A, Dechesne A, Mines PD, Smets BF (2018) Comammox Nitrospira are abundant ammonia oxidizers in diverse groundwater-fed rapid sand filter communities. Environ Microbiol 20(3):1002-1015

Gao D, Liu F, Xie Y, Liang H (2018) Temporal and spatial distribution of ammonia-oxidizing organisms of two types of wetlands in Northeast China. Appl Microbiol Biotechnol 102(16):7195-7205

Gieseke A, Bjerrum L, Wagner M, Amann R (2003) Structure and activity of multiple nitrifying bacterial populations co-existing in a biofilm. Environ Microbiol 5(5):355-369

He Z, Zhang H, Gao S, Lercher MJ, Chen W-H, Hu S (2016) Evolview v2: an online visualization and management tool for customized and annotated phylogenetic trees. Nucleic Acids Res 44(W1):W236-W241

He X, Wu J-P, Jiao L-J, Wen X-M, Wand Y, Ou L-J, Hong Y-G, (2018) Development of a method for ammonia-oxidizing archaea diversity analysis based on amoA gene amplicons with high-throughput sequencing. Microbiol China 45(9):1861-1870

Hellinga C, Schellen AAJC, Mulder JW, van Loosdrecht MCM, Heijnen JJ (1998) The sharon process: an innovative method for nitrogen removal from ammonium-rich waste water. Water Sci Technol 37(9):135-142

Hong Y, Wang Y, Wu J, Jiao L, He X, Wen X, Zhang H, Chang X (2018) Developing a mathematical modeling method for determining the potential rates of microbial ammonia oxidation and nitrite oxidation in environmental samples. Int Biodeterior Biodegrad 133:116-123

Hong Y, Jiao L, Wu J (2020) New primers, taxonomic database and cut-off value for processing $n \times r B$ gene high-throughput sequencing data by MOTHUR. J Microbiol Methods 173:105939

Hovanec TA, DeLong EF (1996) Comparative analysis of nitrifying bacteria associated with freshwater and marine aquaria. Appl Environ Microbiol 62(8):2888-2896

Hovanec TA, Taylor LT, Blakis A, Delong EF (1998) Nitrospira-like bacteria associated with nitrite oxidation in freshwater aquaria. Appl Environ Microbiol 64(1):258-264

Hu H-W, He J-Z (2017) Comammox-a newly discovered nitrification process in the terrestrial nitrogen cycle. J Soils Sediments 17(12):2709-2717

Jetten MSM, Strous M, van de Pas-Schoonen KT, Schalk J, van Dongen UGJM, van de Graaf AA, Logemann S, Muyzer G, van Loosdrecht MCM, Kuenen JG (1998) The anaerobic oxidation of ammonium. FEMS Microbiol Rev 22(5):421-437

Jiao L, Wu J, He X, Wen X, Li Y, Hong Y (2018) Significant microbial nitrogen loss from denitrification and anammox in the land-sea interface of low permeable sediments. Int Biodeterior Biodegrad 135:80-89

Jin T, Zhang T, Yan Q (2010) Characterization and quantification of ammoniaoxidizing archaea (AOA) and bacteria $(A O B)$ in a nitrogen-removing reactor using T-RFLP and qPCR. Appl Microbiol Biotechnol 87(3):1167-1176

Juretschko S, Timmermann G, Schmid M, Schleifer KH, Pommerening-Röser A, Koops HP, Wagner M (1998) Combined molecular and conventional analyses of nitrifying bacterium diversity in activated sludge: Nitrosococcus mobilis and Nitrospira-like bacteria as dominant populations. Appl Environ Microbiol 64(8):3042-3051

Kartal B, van Niftrik L, Rattray J, van de Vossenberg JL, Schmid MC, Sinninghe Damsté J, Jetten MS, Strous M (2008) Candidatus "Brocadia fulgida": an autofluorescent anaerobic ammonium oxidizing bacterium. FEMS Microbiol Ecol 63(1):46-55

Kartal B, de Almeida NM, Maalcke WJ, Op den Camp HJM, Jetten MSM, Keltjens JT (2013) How to make a living from anaerobic ammonium oxidation. FEMS Microbiol Rev 37(3):428-461

Ke X, Lu Y (2012) Adaptation of ammonia-oxidizing microorganisms to environment shift of paddy field soil. FEMS Microbiol Ecol 80(1):87-97

Kim YM, Cho HU, Lee DS, Park C, Park D, Park JM (2011a) Response of nitrifying bacterial communities to the increased thiocyanate concentration in predenitrification process. Bioresour Technol 102(2):913-922

Kim YM, Cho HU, Lee DS, Park D, Park JM (2011b) Influence of operational parameters on nitrogen removal efficiency and microbial communities in a full-scale activated sludge process. Water Res 45(17):5785-5795

Kuai L, Verstraete W (1998) Ammonium removal by the oxygen-limited autotrophic nitrification-denitrification system. Appl Environ Microbiol 64(11):4500-4506

Kuenen JG (2008) Anammox bacteria: from discovery to application. Nat Rev Microbiol 6(4):320-326

Kuypers MMM, Marchant HK, Kartal B (2018) The microbial nitrogen-cycling network. Nat Rev Microbiol 16(5):263-276

Lan C-J, Kumar M, Wang C-C, Lin J-G (2011) Development of simultaneous partial nitrification, anammox and denitrification (SNAD) process in a sequential batch reactor. Bioresour Technol 102(9):5514-5519

Li Y, Hong Y, Wu J, Wang Y, Ye F (2020) Spatial variability pattern of the anaerobic ammonia-oxidizing bacterial community across a salinity gradient from river to ocean. Ecotoxicol. 30(8):1743-53

Limpiyakorn T, Sonthiphand P, Rongsayamanont C, Polprasert C (2011) Abundance of amoA genes of ammonia-oxidizing archaea and bacteria in activated sludge of full-scale wastewater treatment plants. Bioresour Technol 102(4):3694-3701

Ma B, Wang S, Cao S, Miao Y, Jia F, Du R, Peng Y (2016) Biological nitrogen removal from sewage via anammox: recent advances. Bioresour Technol 200:981-990

Meng H, Yang Y-C, Lin J-G, Denecke M, Gu J-D (2017) Occurrence of anammox bacteria in a traditional full-scale wastewater treatment plant and successful inoculation for new establishment. Int Biodeterior Biodegrad 120:224-231

Meng H, Zhang X, Zhou Z, Luo L, Gu JD (2021) Simultaneous occurrence and analysis of both anammox and $n$-damo bacteria in five full-scale wastewater treatment plants. Int Biodeterior Biodegrad 156:105112

Niu J, Kasuga I, Kurisu F, Furumai H, Shigeeda T (2013) Evaluation of autotrophic growth of ammonia-oxidizers associated with granular activated carbon used for drinking water purification by DNA-stable isotope probing. Water Res 47(19):7053-7065

Okabe S, Oshiki M, Takahashi Y, Satoh H (2011) $\mathrm{N}_{2} \mathrm{O}$ emission from a partial nitrification-anammox process and identification of a key biological process of $\mathrm{N}_{2} \mathrm{O}$ emission from anammox granules. Water Res 45(19):6461-6470

Pan K-L, Gao J-F, Fan X-Y, Li D-C, Dai H-H (2018a) The more important role of archaea than bacteria in nitrification of wastewater treatment plants in cold season despite their numerical relationships. Water Res 145:552-561

Pan K-L, Gao J-F, Li H-Y, Fan X-Y, Li D-C, Jiang H (2018b) Ammonia-oxidizing bacteria dominate ammonia oxidation in a full-scale wastewater treatment plant revealed by DNA-based stable isotope probing. Bioresour Technol 256:152-159

Rotthauwe JH, Witzel KP, Liesack W (1997) The ammonia monooxygenase structural gene $a m o A$ as a functional marker: molecular fine-scale analysis of natural ammonia-oxidizing populations. Appl Microbiol Biotechnol 63(12):4704-4712

Schloss PD, Westcott SL, Ryabin T, Hall JR, Hartmann M, Hollister EB, Lesniewski RA, Oakley BB, Parks DH, Robinson CJ, Sahl JW, Stres B, Thallinger GG, Van Horn DJ, Weber CF (2009) Introducing mothur: open-source, platformindependent, community-supported software for describing and comparing microbial communities. Appl Environ Microbiol 75(23):7537-7541 
Schramm A, De Beer D, Wagner M, Amann R (1998) Identification and activities in situ of Nitrosospira and Nitrospira spp. as dominant populations in a nitrifying fluidized bed reactor. Appl Environ Microbiol 64(9):3480

Semedo M, Lopes E, Baptista MS, Oller-Ruiz A, Gilabert J, Tomasino MP, Magalhães C (2021) Depth profile of nitrifying archaeal and bacterial communities in the remote oligotrophic waters of the north pacific. Front Microbiol 12:319

Siripong S, Rittmann BE (2007) Diversity study of nitrifying bacteria in full-scale municipal wastewater treatment plants. Water Res 41(5):1110-1120

Sliekers AO, Derwort N, Gomez JLC, Strous M, Kuenen JG, Jetten MSM (2002) Completely autotrophic nitrogen removal over nitrite in one single reactor. Water Res 36(10):2475-2482

Sri Shalini S, Joseph K (2012) Nitrogen management in landfill leachate: application of SHARON, ANAMMOX and combined SHARON-ANAMMOX process. Waste Manage 32(12):2385-2400

Stéphanie O, Gouy M, Navarro E, Normand P (1994) Molecular phylogenetic analysis of Nitrobacter spp. Int J Syst Evol Microbiol 44(1):83-86

Strous M, Heijnen JJ, Kuenen JG, Jetten MSM (1998) The sequencing batch reactor as a powerful tool for the study of slowly growing anaerobic ammonium-oxidizing microorganisms. Appl Microbiol Biotechnol 50(5):589-596

Strous M, Kuenen JG, Jetten MS (1999) Key physiology of anaerobic ammonium oxidation. Appl Environ Microbiol 65(7):3248-3250

Van de Graaf AA, Mulder A, de Bruijn P, Jetten M, Robertson LA, Kuenen JG (1995) Anaerobic oxidation of ammonium is a biologically mediated process. Appl Environ Microbiol 61(4):1246-1251

van der Star WRL, Abma WR, Blommers D, Mulder J-W, Tokutomi T, Strous M, Picioreanu C, van Loosdrecht MCM (2007) Startup of reactors for anoxic ammonium oxidation: experiences from the first full-scale anammox reactor in Rotterdam. Water Res 41(18):4149-4163

van Dongen U, Jetten MSM, van Loosdrecht MCM (2001) The SHARONAnammox process for treatment of ammonium rich wastewater. Water Sci Technol 44(1):153-160

Wagner M, Rath G, Koops H-P, Flood J, Amann R (1996) In situ analysis of nitrifying bacteria in sewage treatment plants. Water Sci Technol 34(1-2):237-244

Wang Y-F, Gu J-D (2013) Higher diversity of ammonia/ammonium-oxidizing prokaryotes in constructed freshwater wetland than natural coastal marine wetland. Appl Microbiol Biotechnol 97(15):7015-7033

Wang X, Wen X, Xia Y, Hu M, Zhao F, Ding K (2012) Ammonia oxidizing bacteria community dynamics in a pilot-scale wastewater treatment plant. PloS ONE 7(4):e36272

Wang S, Deng L, Zheng D, Wang L, Zhang Y, Yang H, Jiang Y, Huang F (2018) Control of partial nitrification using pulse aeration for treating digested effluent of swine wastewater. Bioresour Technol 262:271-277

Wang L, Hong Y, Gu J-D, Wu J, Yan J, Lin J-G (2021) Influence of critical factors on nitrogen removal contribution by anammox and denitrification in an anammox-inoculated wastewater treatment system. J Water Process Eng 40:101868

Wells GF, Park HD, Yeung CH, Eggleston B, Francis CA, Criddle CS (2009) Ammonia-oxidizing communities in a highly aerated full-scale activated sludge bioreactor: betaproteobacterial dynamics and low relative abundance of Crenarchaea. Environ Microbiol 11(9):2310-2328

Wu J, Hong Y, He X, Jiao L, Wen X, Chen S, Chen G, Li Y, Huang T, Hu Y, Liu X (2018) Anaerobic ammonium oxidation in acidic red soils. Front Microbiol 9:2142

Wu J, Hong Y, Ye J, Li Y, Wang Y (2019) Diversity of anammox bacteria and contribution to the nitrogen loss in surface sediment. Int Biodeterior Biodegrad 142:227-234

Xin X, Liu Q, Werner D, Lu H, Qin J (2020) Start-up strategy and bacterial community analysis of SNAD process for treating anaerobic digester liquor of swine wastewater (ADLSW) in a continuous-flow biofilm reactor. Water Environ J 34(S1):661-671

Yang Y, Zhang J, Zhao Q, Zhou Q, Li N, Wang Y, Xie S, Liu Y (2016) Sediment Ammonia-oxidizing microorganisms in two plateau freshwater lakes at different trophic states. Microb Ecol 71(2):257-265

Yang Y, Li M, Li X-Y, Gu J-D (2018) Two identical copies of the hydrazine synthase gene clusters found in the genomes of anammox bacteria. Int Biodeterior Biodegrad 132:236-240

Yang Y, Li M, Hu Z, Shim H, Lin J-G, Li X-Y, Gu J-D (2020) Deep insights into the green nitrogen removal by anammox in four full-scale WWTPs treating landfill leachate based on 165 rRNA gene and transcripts by 165 rRNA high-throughput sequencing. J Clean Prod 276:124176

Yang Y, Pan J, Zhou Z, Wu J, Liu Y, Lin J-G, Hong Y, Li X, Li M, Gu J-D (2020) Complex microbial nitrogen-cycling networks in three distinct anammoxinoculated wastewater treatment systems. Water Res 168:115142

Yang Y, Herbold CW, Jung M-Y, Qin W, Cai M, Du H, Lin J-G, Li X, Li M, Gu J-D (2021) Survival strategies of ammonia-oxidizing archaea (AOA) in a fullscale WWTP treating mixed landfill leachate containing copper ions and operating at low-intensity of aeration. Water Res 191:116798

Yapsakli K (2010) Co-occurrence of nitrogen-converting organisms in full-scale treatment plants. J Environ Sci Health Part A 45(9):1060-1070

Zhang L-M, Duff AM, Smith CJ (2018) Community and functional shifts in ammonia oxidizers across terrestrial and marine (soil/sediment) boundaries in two coastal bay ecosystems. Environ Microbiol 20(8):2834-2853

Zheng Z, Li J, Ma J, Du J, Wang F, Bian W, Zhang Y, Zhao B (2017) Inhibition factors and kinetic model for ammonium inhibition on the anammox process of the SNAD biofilm. J Environ Sci 53:60-67

Zhou L, Wang S, Zou Y, Xia C, Zhu G (2015) Species, abundance and function of ammonia-oxidizing archaea in inland waters across china. Sci Rep 5(1):15969

\section{Publisher's Note}

Springer Nature remains neutral with regard to jurisdictional claims in published maps and institutional affiliations.

\section{Submit your manuscript to a SpringerOpen ${ }^{\circ}$ journal and benefit from:}

- Convenient online submission

- Rigorous peer review

- Open access: articles freely available online

- High visibility within the field

- Retaining the copyright to your article

Submit your next manuscript at $\gg$ springeropen.com 